\title{
Grallator theropod tracks from the Late Jurassic of Asturias (Spain): ichnotaxonomic implications
}

\author{
Diego CASTANERA ${ }^{1,2 *}$, Laura PIÑUELA ${ }^{3}$ \& José C. GARCÍA-RAMOS ${ }^{3}$
}

\footnotetext{
${ }^{1}$ Bayerische Staatssammlung für Paläontologie und Geologie and GeoBioCenter, Ludwig-Maximilians-Universität Munich, Richard-Wagner-Str.10, D-80333 Munich, Germany. dcastanera@hotmail.es; d.castanera@1rz.uni-muenchen.de

${ }^{2}$ Aragosaurus-IUCA, Paleontología, Facultad de Ciencias, Universidad de Zaragoza, 50009, Zaragoza, Spain

${ }^{3}$ Museo del Jurásico de Asturias (MUJA) 33328, Colunga Asturias, Spain. lpinuela.muja@gmail.com; jcgramos.muja@gmail.com

* Corresponding author
}

Castanera, D., Piñuela, L. \& García-Ramos, J.C. 2016. Grallator theropod tracks from the Late Jurassic of Asturias (Spain): ichnotaxonomic implications. [Icnitas de terópodo Grallator del Jurásico Superior de Asturias (España): implicaciones taxonómicas]. Spanish Journal of Palaeontology, 31 (2), 283-296.

\section{ABSTRACT}

The MUJA (Museo del Jurásico de Asturias, Jurassic Museum of Asturias) has an interesting collection of theropod tracks that show similarities with the ichnogenera assigned to the Eubrontes-Grallator plexus. In this paper we describe in detail the morphology of 21 specimens recovered from different localities on "The Dinosaur Coast" of Asturias, plus four specimens preserved in outcrops in the sea cliffs of Les Vinaes (Villaviciosa). All the specimens are from the outcrops of the Lastres Formation, which is Kimmeridgian in age. The general morphology of the tracks, the footprint length-width ratio, the mesaxony, low divarication of the digits (II-IV) and the absence of hallux and metatarsophalangeal impressions suggest that the tracks are more similar to Grallator than to any other theropod ichnotaxa. Geometric morphometric analysis (principal component analysis, PCA) based on 2D landmark techniques suggests that they differ from Kalohipus bretunensis (as yet the only Grallator-like ichnotaxon described in the Iberian Peninsula) mainly in the divarication angles and in the projection of digit III.

Keywords: Grallatorid tracks, Eubrontes-Grallator plexus, geometric morphometrics, Kimmeridgian.

\section{RESUMEN}

El MUJA (Museo del Jurásico de Asturias) posee una interesante colección de icnitas de terópodos que presentan similitudes con los icnogéneros asignados al EubrontesGrallator plexus. En este trabajo se describe en detalle la morfología de una selección de 21 ejemplares recuperados de los acantilados de "La Costa de los Dinosaurios" y 4 ejemplares preservados en los acantilados de Les Vinaes (Villaviciosa). Todos ellos proceden de los afloramientos de la Formación Lastres, cuya edad es Kimmeridgiense. La morfología general de las icnitas, la relación longitud-anchura, la mesaxonía, el bajo ángulo interdigital (II-IV) o la ausencia de hallux y de impresiones metatarsofalangeanas indican que las icnitas se asemejan más a Grallator que a cualquier otro icnotaxón de terópodo. Análisis de morfometría geométrica (análisis de componentes principales, PCA) basados en técnicas con landmarks en 2D sugieren que se distinguen de Kalohipus bretunensis (hasta la fecha el único icnotaxón del tipo Grallator descrito en la Península Ibérica) principalmente en el ángulo interdigital y en la proyección del dedo III.

Palabras clave: Icnitas gallatóridas, Eubrontes-Grallator plexus, morfometría geométrica, Kimmeridgiense. 


\section{INTRODUCTION}

The Asturian sea cliffs have yielded an outstanding collection of vertebrate tracks, including those of dinosaurs, pterosaurs, crocodylomorphs, turtles and lizards. The collection provides an ancient window onto the Late Jurassic ecosystems of Iberia, and the ichnofauna represented makes the Asturian sea cliffs one of the Late Jurassic deposits with the greatest ichnodiversity worldwide (García-Ramos et al., 2002, 2004, 2006; Lockley et al., 2008; Piñuela, 2015). Among these vertebrate tracks the theropod tracks are particularly noteworthy. These have previously been classified according to three general morphotypes: 'Grallatorid', 'Kayentapus-Magnoavipes' and 'Hispanosauropus' (Avanzini et al., 2012). Recently, Piñuela (2015) have suggested that the 'Grallatorid' morphotype might be classified inside the ichnogenus Grallator.

Typical grallatorid tracks are characterised by their small-size, well-defined digital pads and by having digits II and IV of similar length, digit III being longer (high mesaxony), an oval/subrounded "heel", and a low interdigital angle. Within this general definition, we can find the classical ichnogenera Grallator, Anchisauripus and Eubrontes (Hitchcock, 1858; Lull, 1904; Olsen et al., 1998). These kinds of tracks have been described worldwide from several tracksites and deposits of the Late Triassic and Early Jurassic (Gierliński, 1991; Gierliński \& Alhberg, 1994; Olsen et al., 1998; Thulborn, 2000; Gatesy et al., 1999; Lucas et al., 2001; 2010; Gaston et al., 2003; Milàn et al., 2004; Clark et al., 2005; Klein \& Haubold, 2007; Petti et al., 2011). Furthermore, in recent years, grallatorid-like tracks have been described from younger deposits in the Middle Jurassic of Argentina (De Valais, 2011), the Late Jurassic and Early Cretaceous of Spain (Piñuela, 2000; Lockley et al., 2008; Pascual-Arribas \& Hernández-Medrano, 2012; Avanzini et al., 2012; Piñuela, 2015), the Late Jurassic of Germany (Diedrich, 2011) and the USA (Lockley \& Gierliński, 2014), and the Late Jurassic and Early Cretaceous of Asia (Lockley et al., 2013, 2014, 2015).

Recent research on the Early Cretaceous grallatoridlike theropod tracks of the Cameros Basin in Spain (Castanera et al., 2015) has demonstrated that they can be classified within the ichnotaxon Kalohipus bretunensis Fuentes Vidarte \& Meijide Calvo (1998). Up to now, this ichnotaxon has only been described in the Early Cretaceous (Berriasian) of Soria Province in Spain, concretely in the deposits of the Huérteles Formation (Fuentes Vidarte \& Meijide Calvo, 1998; Pascual-Arribas \& HernándezMedrano, 2012; Castanera et al., 2015). The latter authors have emphasized, as other authors previously did (RasskinGutman et al., 1997; Rodrigues \& Santos, 2004; Clark \& Brett-Surman, 2008), how geometric morphometric techniques might be an useful tool for studying tracks from an ichnotaxonomical point of view. The similarities between the tracks assigned to Kalohipus bretunensis by Castanera et al. (2015) and the 'Grallatorid' morphotype/ Grallator tracks described in the Late Jurassic of Asturias are noteworthy (Lockley et al., 2008; Avanzini et al., 2012; Piñuela, 2015). The aim of this paper is to describe in detail the 'Grallatorid' morphotype/Grallator tracks of the MUJA collection and to determine whether these theropod tracks from Asturias can be classified in one of the aforementioned ichnotaxa (the Grallator-Eubrontes plexus or Kalohipus). Furthermore, these tracks are also compared with other Grallator-like tracks, especially from Asia, in order to rule out other possible ichnotaxa.

\section{GEOGRAPHICAL AND GEOLOGICAL SETTING}

All tracks in the studied sample are from several localities in the Late Jurassic coastal exposures of Asturias (Fig. 1). The localities are situated between Ribadesella (in the east) and Gijon (in the west), a sector $60 \mathrm{~km}$ long known as "The Dinosaur Coast". The specific locality of each track is shown in Table 1. All the tracks came from track-bearing layers of the Lastres Formation.

This formation is about $400 \mathrm{~m}$ thick and is composed of grey sandstones, conglomerates, mudstones and marls. The palaeoenvironmental setting of the formation has been interpreted as a fluvial-dominated deltaic system (GarcíaRamos \& Gutiérrez Claverol, 1995; García-Ramos et al., 2002, 2004, 2006). Many tracks were produced in a firm, muddy substrate and then filled by sand, so all the studied tracks have been preserved as sandstone casts. Most of them represent the infilling by sand of a true track produced in mud, but there are also several tracks that were produced in moist sand.

\section{MATERIALS AND METHODS}

Most of the tracks (see Table 1) are part of the track collection housed in the Museo Jurásico de Asturias (MUJA). These tracks are referred to by the acronym MUJA followed by the registration number. The other four tracks included in the analysis come from Les Vinaes tracksite (Villaviciosa) and are referred to by the letters LV.

The terminology used in the description of the tracks mainly follows Thulborn (1990). Thus, the footprint length (FL), footprint width (FW), length of digits II, III and IV, and divarication angles (II-III; III-IV) have been measured (Fig. 2). Subsequently, the FL/FW ratio has been calculated. These measurements have been taken 


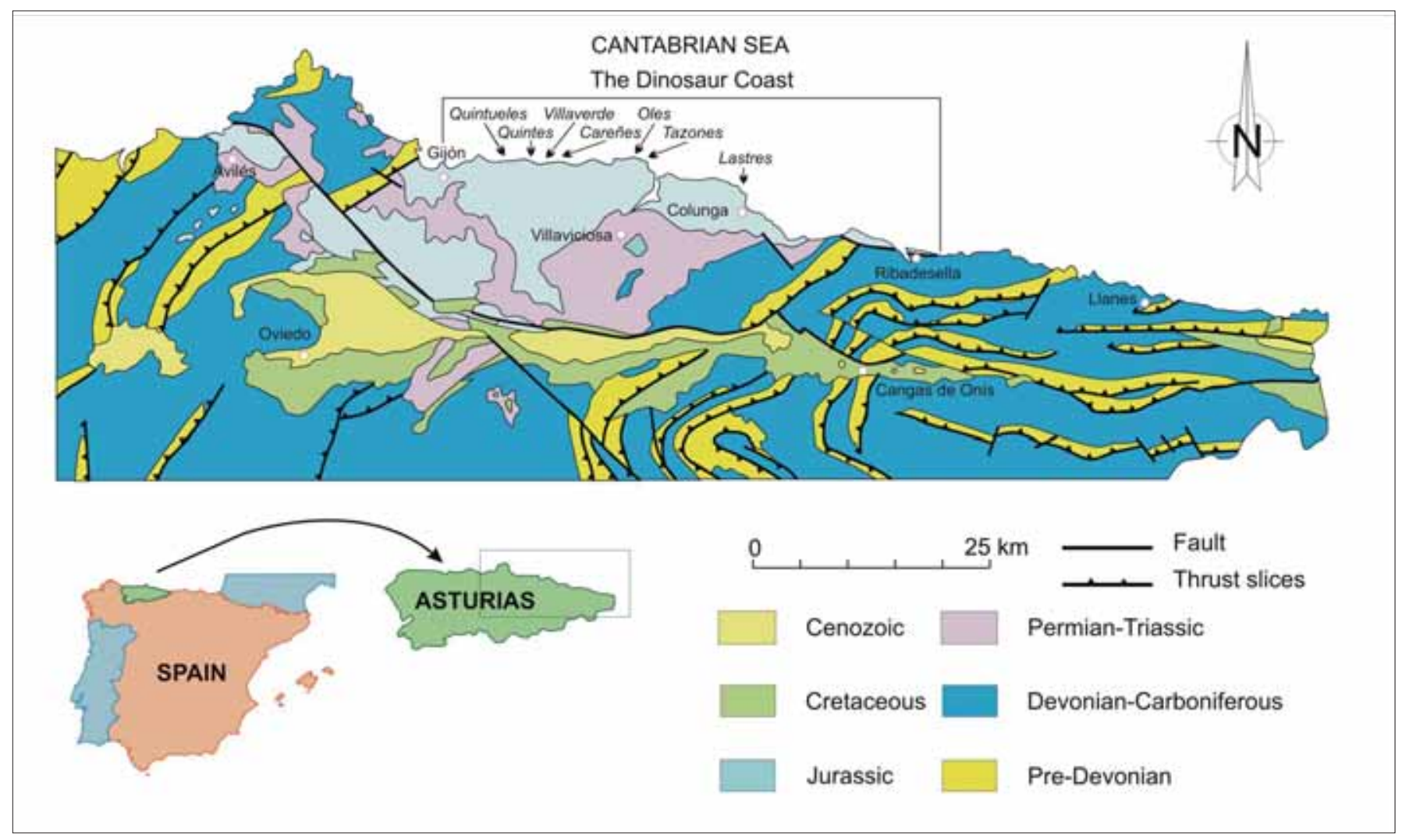

Figure 1. Geographical and geological setting of footprint localities along "The Dinosaur Coast" of Asturias, Spain. Modified from García-Ramos \& Gutiérrez Claverol (1995).

Table 1. List of the studied specimens housed in the Museo Jurásico de Asturias (MUJA) and preserved in the Les Vinaes (LV) cliff. * denotes the best preserved tracks.

\begin{tabular}{|c|c|c|c|c|}
\hline Track & Locality & left/right & size (FL) & Notes/Remarks \\
\hline MUJA-4557 & Villaverde & left & 17,3 & \\
\hline MUJA-1048 & Villaverde & left & 13 & Landmark 6 inferred. Studied in Avanzini et al. (2011) \\
\hline MUJA-1890 & Quintes & left & 15 & Heel not preserved. Landmark 6 completely inferred. Not represented in Figs 6, 7. \\
\hline MUJA-0627 & Oles & right & 11,5 & \\
\hline MUJA-3825 & Villaverde & right & 8,7 & Landmark 8 and 10 inferred \\
\hline MUJA-1049 & Quintes & right & 12,1 & AT strange, digit II quite long \\
\hline MUJA-1262 & Quintes & left & 17,2 & Landmark 1 inferred; Fig. 4I in Lockley et al . (2008) \\
\hline MUJA-4124 & Careñes & right & 7,9 & \\
\hline MUJA-1059 & Oles & left & 9 & $\begin{array}{l}\text { Heel not preserved. Landmarks } 1 \text { (FL) and } 6 \text { inferred; } \\
\text { Fig. 1A Azanzini et al. (2011); Not represented in Figs 6, } 7 .\end{array}$ \\
\hline MUJA-3822* & Villaverde & right & 18,5 & Heel poorly preserved. Landmark 6 inferred \\
\hline MUJA-1074* & Quintes & right & 19 & Fig. 4G in Lockley et al . (2008) \\
\hline MUJA-1072 & Quintes & right & 18 & Fig. 4H in Lockley et al . (2008); Studied in Avanzini et al . (2011); landmark 6 (FL) inferred \\
\hline MUJA-1075* & Quintes & left & 14 & Heel poorly preserved. Landmark 6, 7, and 9 inferred \\
\hline MUJA-1071* & Lastres & right & 16,8 & Heel not preserved. Landmarks 1 and 6 inferred; Fig. 4F in Lockley et al. (2008) \\
\hline MUJA-1103 & Quintueles & left & 17,2 & Fig. 1A Azanzini et al. (2011) \\
\hline MUJA-4524 & Villaverde & right & 13 & Heel poorly preserved. Landmark 6 inferred \\
\hline MUJA-1113 & Quintes & right & 16,5 & Heel poorly preserved. Landmark 6 inferred \\
\hline MUJA-4339 & Villaverde & left & 16,5 & Landmark 1 inferred \\
\hline MUJA-3824.2 & Villaverde & right & 20,5 & Landmark 6 inferred \\
\hline LV4* & Villaverde & right & 18,4 & Les Vinaes tracksite upper level \\
\hline LV2* & Villaverde & right & 17,5 & Les Vinaes tracksite upper level \\
\hline LV3 & Villaverde & right & 21,5 & Les Vinaes tracksite upper level. Heel poorly preserved \\
\hline LV1 & Villaverde & left & 19,3 & Les Vinaes tracksite lower level \\
\hline MUJA-1260 & Quintes & left & 17,2 & \\
\hline MUJA-1894* & Villaverde & right & 15 & Landmarks 3, 7, 9 inferred; Fig. 4D in Lockley et al . (2008) \\
\hline
\end{tabular}


with the software Image J. The tracks have been classified into different size classes following Marty (2008), who classified bipedal tracks on the basis of pes length (FL) as: 1) minute, $\mathrm{FL}<10 \mathrm{~cm}$; 2) small, $10 \mathrm{~cm}<\mathrm{FL}<20$ $\mathrm{cm}$; 3) medium, $20 \mathrm{~cm}<\mathrm{FL}<30 \mathrm{~cm}$; and 4) large, $\mathrm{FL}$ $>30 \mathrm{~cm}$. The tracks have been compared in a bivariate plot (length/width ratio vs mesaxony) with other theropod ichnotaxa. The mesaxony has been calculated on the basis of the anterior triangle length-width ratio (AT) in accordance with Lockley (2009). These data have been analysed with the software PAST v.2.14 (Hammer et al., 2001). The data for the length/width ratio and AT of the theropod ichnotaxa have been taken from Lockley (2009) and Xing et al. (2014).

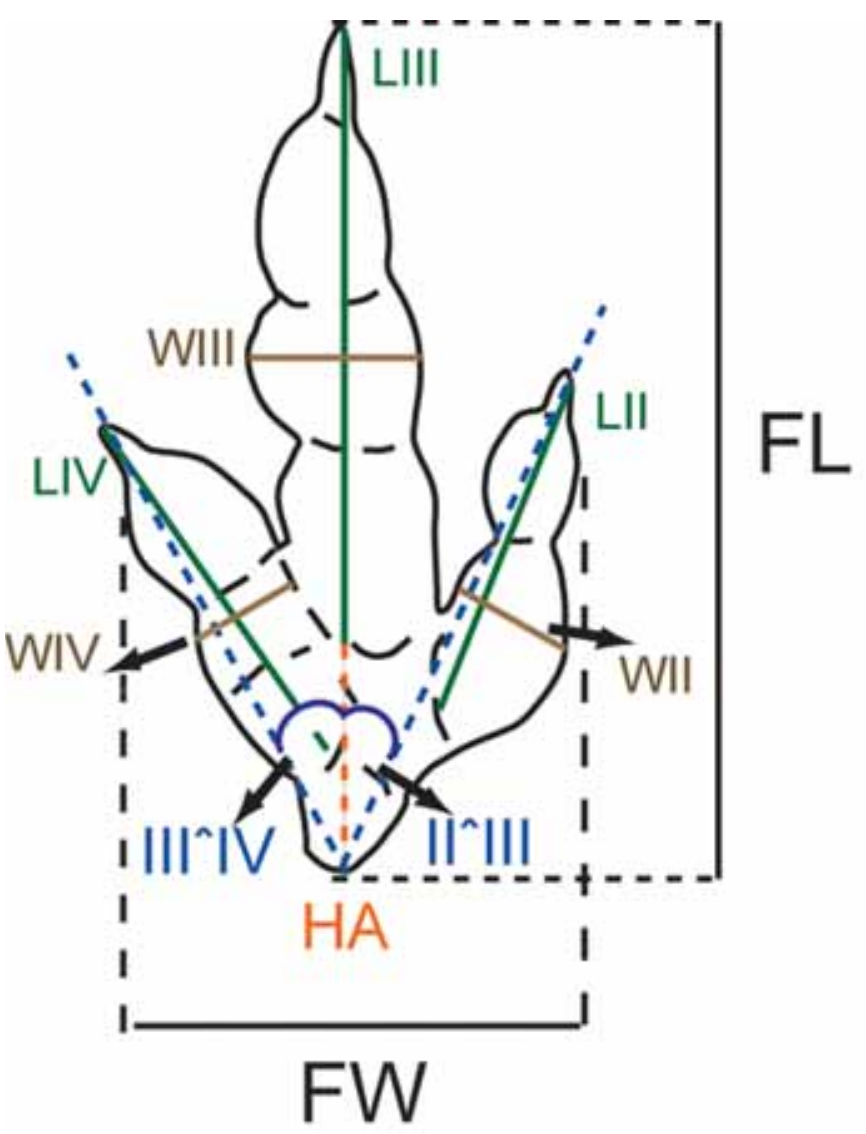

Figure 2. Measurements taken from the tracks with the specimen MUJA-1894 as example (redrawn from Piñuela, 2000). Footprint length (FL), footprint width (FW), digit length (LI, LII, LIII), digit width (WI, WII, WIII), "heel" area (HA), divarication angles (II-III, III-IV).

To perform the geometric morphometric analysis with the landmarks (see below) we have followed the same methodological procedure used by Castanera et al. (2015). Thus, each specimen was photographed with a Panasonic Lumix DMC-FZ7. The pictures were modified as necessary with Adobe Photoshop to analyse the track morphology as if all the tracks were left tracks (the right tracks have been mirrored). The brightness, contrast and colour levels were modified in some pictures. The majority of the tracks are isolated imprints, so the criterion for discriminating between left and right was the location of a medial notch that represents the proximal part of digit II in classical grallatorid tracks (see Olsen et al., 1998). Further, the claw mark of digit III is always oriented to the medial side (pointing towards digit II).

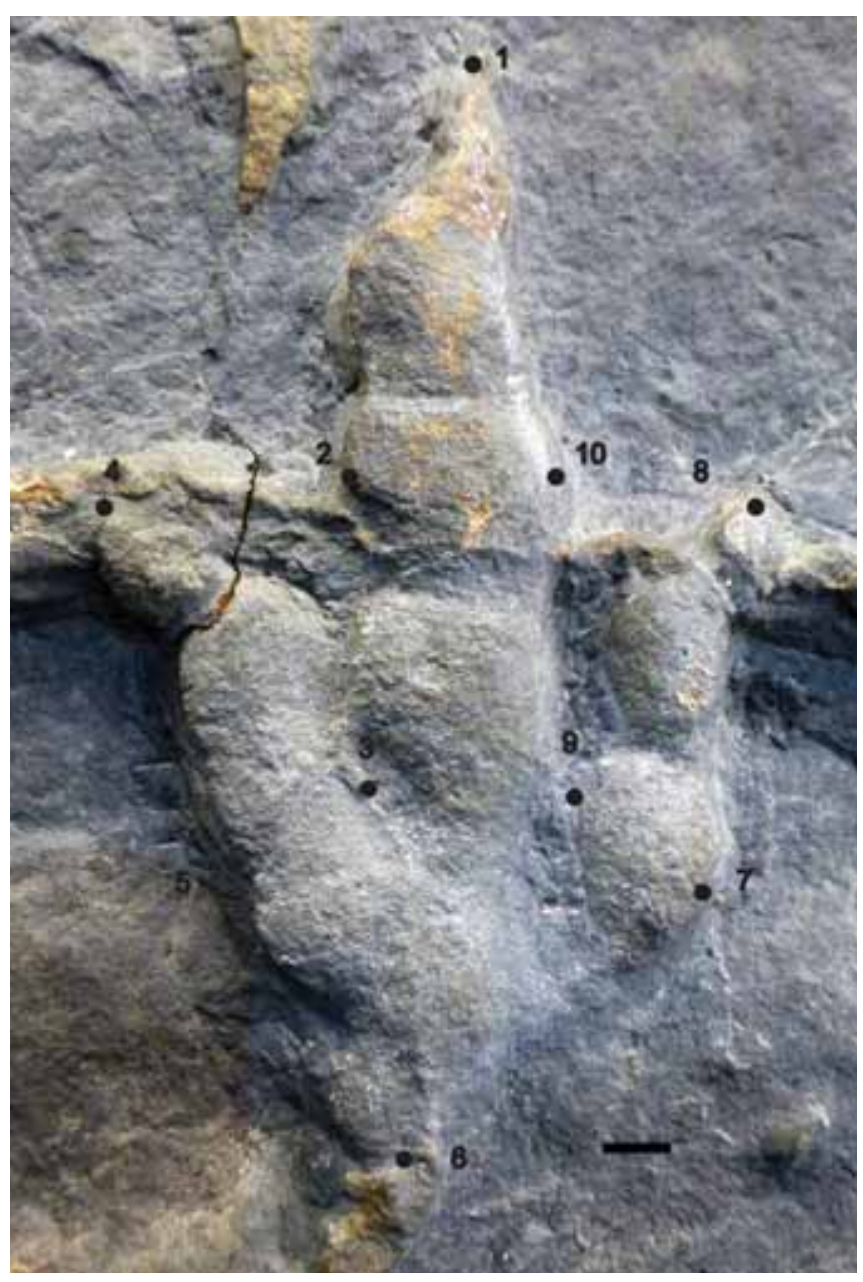

Figure 3. Picture of the specimen MUJA-1894 with the 10 selected landmarks that represent the most distal position and the maximum width of the digits and the position of the "heel". Scale $=1 \mathrm{~cm}$.

We selected the same set of 10 landmarks (Fig. 3) described by Castanera et al. (2015) that represent the most distal position and the maximum width of the digits and the position of the "heel". The reasons for not including other areas of the track (e.g. hypices) and some aspects of the setting of the landmarks have already been discussed in Castanera et al. (2015). The landmarks were digitized 
from the photographs of the specimens using TpsDig v.2.16 (http://life.bio.sunysb.edu/morph/). The data were exported to PAST v.2.14 (Hammer et al., 2001). A Procrustes-fitting transformation (rotated to the major axis) of the data was applied to standardize the alignment of each landmark in relation to different sizes and orientations of the tracks (see Methods in Colmenar et al., 2014; pp. 2-6). The landmarks selected in the type material of Grallator, Anchisauripus and Eubrontes were taken from Olsen et al. (1998, figs $4 \mathrm{E}, \mathrm{H}, 6 \mathrm{~B}, 8,10)$. A principal component analysis (PCA) was carried out. Analysis of the clusters and the loadings obtained in the PCA helps to determine the most relevant variables for their differentiation.

\section{SYSTEMATIC PALAEOICHNOLOGY}

Ichnofamily Grallatoridae Lull, 1904

Ichnogenus Grallator Hitchcock, 1858

Grallator isp.

(Figs 3-7)

2008 'Grallatorid' morphotype; Lockley, GarcíaRamos, Piñuela, Avanzini, p. 56, Fig. 4.

2011 'Grallatorid' morphotype; Avanzini, Piñuela, García-Ramos, p.2, Fig. 1A.
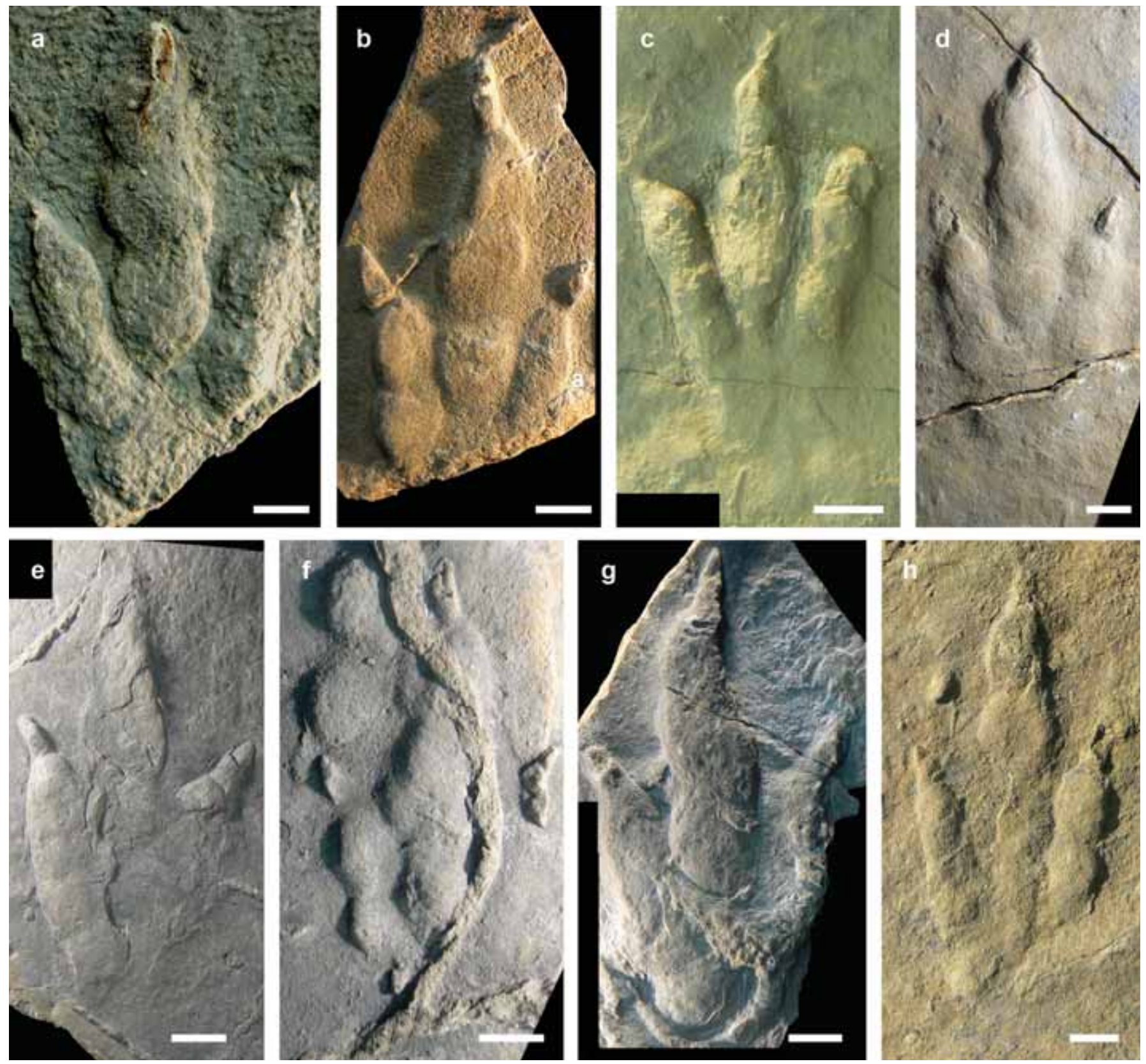

Figure 4. Pictures of a selection of some of the best-preserved footprints. a) MUJA-4457; b) MUJA-1890; c) MUJA-1049; d) MUJA3822; e) MUJA-1071; f) MUJA-1075; g) MUJA-1074; h) LV4. Scale $=2 \mathrm{~cm}$. 
2015 Morphotype A (Grallator); Piñuela, p.82-84, Figs.9.1.3-9.1.5; p.90, Table 9.1.1.

Referred specimens. Twenty-five footprints. MUJA4557, MUJA-1048, MUJA-1890, MUJA-0627, MUJA3825, MUJA-1049, MUJA-1262, MUJA-4124, MUJA1059, MUJA-3822, MUJA-1074, MUJA-1072, MUJA1075, MUJA-1071, MUJA-1103, MUJA-4524, MUJA1113, MUJA-4339, MUJA-3824.2, MUJA-1260, MUJA1894, LV1, LV2, LV3, LV4.

Description. Minute to medium-size $(7-21.5 \mathrm{~cm})$ tridactyl tracks (Fig. 4), much longer than wide (FL/FW ratio $=1.73-2.5)($ Table 2$)$. The digits are slender with an acuminate end and clear claw marks preserved. Digit III is clearly longer and slightly wider than digits II and IV, which are almost equal in length (digit IV being slightly longer) and width. The mesaxony is quite variable (AT = 0.69 ?-1.12), but is high in the majority of the specimens (more than 0.8) (Table 2). The divarication angle II-IV is low $\left(32-55^{\circ}\right)$ and the hypices are quite symmetrical (Table 2). The "heel" is oval to round in morphology and asymmetrical due to a small medial notch located behind digit II. Well-defined digital pads can be discerned, suggesting a phalangeal formula of 2-3-4 (including the metatarsophalangeal pad IV).

\section{DISCUSSION}

The general morphology of the tracks is reminiscent of the theropod ichnotaxa assigned to Grallator-AnchisauripusEubrontes (Fig. 5), the so-called Eubrontes-Grallator plexus (Olsen et al., 1998; Lockley, 2009). These tracks are mainly characterized by three digits, digit III being the longest and digits II-IV smaller and subequal in length, and by having a low divarication angle. There has been an intense debate regarding the validity of the three ichnotaxa and whether they might be synonyms differentiated on

Table 2. Measurements of the specimens. Footprint length (FL), footprint width (FW), footprint length /footprint width ratio (FL/ FW), digit length (LI, LII, LIII), digit width (WI, WII, WIII), "heel” area (HA), divarication angles (II-III, III-IV), mesaxony (AT, anterior triangle ratio).

\begin{tabular}{|c|c|c|c|c|c|c|c|c|c|c|c|c|c|}
\hline Track & FL & FW & $\begin{array}{l}\text { FL/ } \\
\text { FW } \\
\end{array}$ & LII & LIII & LIV & WII & WIII & WIV & HA & $\mathbf{I I}^{\wedge} \mathbf{I I I}$ & IIII'IV & AT \\
\hline MUJA-4557* & 17.5 & 9.9 & 1.76 & 8.2 & 12.7 & 8.6 & 2.1 & 3.1 & 2.6 & $4.6(26 \%)$ & 25 & 21 & 0.75 \\
\hline MUJA-1048 & 13 & & 2 & 5.9 & 8.9 & $7.5 ?$ & 1.5 & .7 & 1.3 & $3.3 ?$ & 23.5 & 16.5 & 0.97 \\
\hline MUJA-1890 & (+) 15 & 7.3 & & (+)6.4 & 12.4 & $(+) 7.9$ & 1.8 & 2.8 & 2.3 & & 24 & 24 & 0.98 \\
\hline MUJA-0627 & 11.7 & 6 & 1.82 & 6 & 8.3 & 5.1 & 1.5 & 1.7 & 1.5 & 3.38 & 25.5 & 24 & 0.72 \\
\hline MUJA-3825 & 8.6 & 4.9 & 1.75 & 3.7 & 6.2 & 3.6 & 1 & 1.3 & 1 & 2,4 & 30 & 21 & 0.9 \\
\hline MUJA-1049* & 11.8 & 6.8 & 1.73 & 5.9 & 8.5 & 5.0 & 1.6 & 1.6 & 1.6 & $?$ & 17 & 26 & 0.73 \\
\hline MUJA-1262 & 16.9 & 8 & 1.94 & 7.8 & 11.5 & 8 & 2.1 & 3.1 & & 5.2 & 24.5 & 21 & 0.76 \\
\hline MUJA-4124 & 7.9 & 3.5 & 2.25 & 3.3 & 6 & 3.4 & 0.7 & 1 & 0.9 & 1.9 & 21.5 & 22 & 0.85 \\
\hline MUJA-1059 & $(+) 8.8$ & 3 & - & 3.8 & $(+) 6.2$ & 4 & & 1.4 & & & 27 & 23 & \\
\hline MUJA-3822 & 18.5 & 8 & 2.3 & 7.5 & 12.7 & $10 ?$ & 2.1 & 2.9 & 2.2 & $5.4(29 \%)$ & 19 & 18 & 0.96 \\
\hline MUJA-1074 & 17.9 & 8.5 & 2.1 & $7.8 ?$ & $12.8 ?$ & 7.5 & 2.1 & 3.3 & 2.2 & $4.9(27 \%)$ & 24 & 22 & 0.75 \\
\hline MUJA-1072 & 17.8 & 9.8 & 1.8 & 7.8 & 14.4 & 10 & 2.4 & 3.1 & 2.4 & 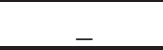 & 27 & 23 & $0.89 ?$ \\
\hline MUJA-1075 & 14.1 & 6.7 & 2.1 & 5.5 & 11.5 & 6.2 & 1 & 1.6 & 1.2 & $3(21 \%)$ & 24.5 & 23 & 0.96 \\
\hline MUJA & 16.1 & 7 & 2.1 & 6.4 & 11.6 & 7.6 & $2 ?$ & $2.1 ?$ & $2.3 ?$ & $4.4 ?$ & 26.5 & 20 & 1 \\
\hline MUJA-1103 & 16.5 & 7.5 & 2.2 & 7.5 & 12.1 & 7 & 2.2 & 2.7 & 2 & 4.5 & 24 & 18 & 0.78 \\
\hline MUJA-4524 & 14.6 & 6.2 & 2.3 & 4.4 & 9.3 & 4.2 & 1.3 & 1.8 & 1.5 & & 22.5 & 24.5 & 1.02 \\
\hline MUJA-1113 & 15 & 6 & 2.5 & 6.4 & 11.4 & 7.1 & 1.4 & 2.1 & 1.7 & 3.6 & 24 & 19 & 1.12 \\
\hline MUJA-4339 & $16.8 ?$ & 8.7 & 1.9 & 8.8 & 12.2 & 7.5 & 2.4 & 3.1 & 2.8 & 4.6 & 26 & 20 & $0.69 ?$ \\
\hline MUJA-3824.2 & 20 & 8.6 & 2.32 & 9 & 13.9 & 6.8 & 1.8 & 2.9 & 1.6 & 6.1 & 19 & 16.5 & 0.88 \\
\hline LV4 & 18 & 7.9 & 2.27 & 7 & 12.4 & 7.3 & 2 & 2.5 & 2 & $5.6(31 \%)$ & 19 & 19.5 & 1.05 \\
\hline LV2 & 17.6 & 8.4 & 2.09 & 7.3 & 12.1 & 7.4 & 2.1 & 2.4 & 2.2 & $5.5(31 \%)$ & 21.5 & 21 & 0.9 \\
\hline LV3 & $21 ?$ & 8.4 & 2.5 & 7.6 & 12.8 & $6.4 ?$ & 1.9 & 2.4 & 2.1 & $8.2 ?$ & 19 & 13 & 0.97 \\
\hline LV1 & 19.3 & 8.8 & 2.19 & 7.7 & 14.5 & 8.5 & 2.7 & $2.7 ?$ & 2.3 & 3.8 & 25 & 17 & 0.92 \\
\hline MUJA-1260 & 17 & 7.4 & 2.29 & $5.2 ?$ & $12.1 ?$ & 6.4 & $1.4 ?$ & 2.4 & $1.6 ?$ & 4.9 & 19 & 22.5 & 1 \\
\hline MUJA-1894 & 16.1 & 8.1 & 1.98 & 6.7 & 11.8 & 7.1 & 2.2 & 3.1 & 2.5 & $4.3(26 \%)$ & 23.5 & 23.5 & 0.8 \\
\hline
\end{tabular}


the basis of size. Given the amount of literature on this topic (Olsen, 1980; Weems, 1992; Olsen et al., 1998; Smith \& Farlow, 2003; Lockley, 2009), a review of the ichnotaxonomic validity of the three ichnotaxa is beyond the scope of this paper. Nonetheless, some brief comments are in order. Olsen (1980) stated that there are differences in proportions between the three ichnogenera, especially in the relative length of digit III. The author graphed this parameter against the remaining length of the foot, noting how the pes impression changed in shape continuously in accordance with size and arguing that the ichnogenera Grallator, Anchisauripus and Eubrontes formed a continuum that might well have corresponded to the tracks of individuals of different ages belonging to a single dinosaur species. Accordingly, the author suggested that "it would be reasonable to synonymize the junior names Eubrontes and Anchisauripus with the senior name Grallator".
Subsequently, Olsen et al. (1998) treated them as distinct ichnogenera although these authors argued that they might display differences derived from allometric growth and the footprints might thus represent different ontogenetic stages of "several related species in one genus or even within one species of trackmaker". On the other hand, Weems (1992) synonymized a number of Anchisauripus ichnospecies and assigned them to Grallator or Eubrontes, considering the distinction between the three ichnotaxa not to be justified. In more recent papers, moreover, other authors have adopted this view and have regarded Grallator and Eubrontes as different ichnotaxa and Anchisauripus as a synonym of Grallator (Lucas et al., 2006; Lockley, 2009; Piñuela, 2015). On the other hand, Rainforth (2005) synonymized the three ichnotaxa under Eubrontes. Nonetheless, some authors (Getty et al., 2015) still use the three ichnotaxa (including Anchisauripus) because they "convey useful information on track size and morphology".
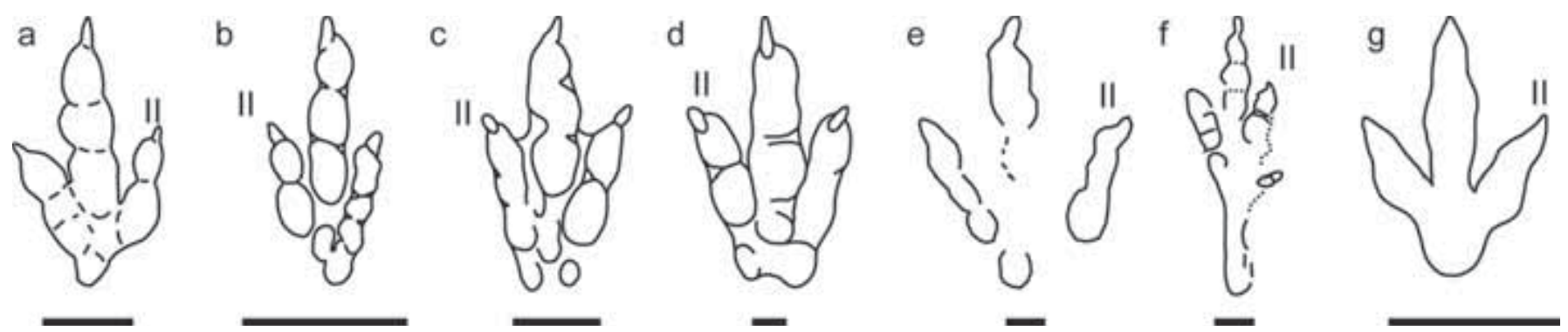

Figure 5. Comparison of the specimen MUJA-1894 (a, redrawn from Piñuela, 2000) with Grallator (b, composite outline redrawn from Olsen et al. 1998), Anchisauripus (c, redrawn from Olsen et al. 1998), Eubrontes (d, redrawn from Olsen et al. 1998), Kayentapus (e, redrawn from Lockley et al., 2011), Jialingpus (f, redrawn from Lockley et al., 2013) and Kalohipus (g, redrawn from Fuentes Vidarte \& Meijide Calvo, 1998). Scale bars $=5 \mathrm{~cm}$.

According to Lull (1904), the main differences between Grallator and Anchisauripus are the footprint size and the presence of a hallux impression in the latter, although Weems (1992) suggested that this mark might be misinterpreted. The studied tracks from Asturias have not preserved any sign of the hallux impression so this would be a considerable difference with respect to Anchisauripus. The footprint size varies among the specimens in the sample. Lockley et al. (2008) and Avanzini et al. (2012) classified some of the tracks (MUJA-1048, MUJA1262, MUJA-1059, MUJA-1071, MUJA-1072, MUJA1074, MUJA-1103, MUJA-1894) as belonging to the "Grallatorid" morphotype. Posteriorly, Avanzini et al. (2012) suggested that the tracks can be divided into two subgroups on the basis of size (maximum length): medium-sized (FL between 17.5 and $20 \mathrm{~cm}$ ), which can be assigned to the ichnogenus Anchisauripus s.s., and smallsized (FL between 8.5 and $15.5 \mathrm{~cm}$ ), which can be related to Grallator s.s. Finally, Piñuela (2015) identified all the specimens studied herein as morphotype A (Grallator). Looking again at the Grallator-Eubrontes plexus (including Anchisauripus), Lockley (2009) measured the relative length of digit III within the ichnogenera, taking into account the mesaxony (see also Weems, 1992), and suggested that the tracks show an increasing size, shifting from narrow to wide, and a decreasing digit III lenght, shifting from strongly to weakly mesaxonic. Thus, Grallator tracks have the greatest anterior projection of digit III and Eubrontes the least, whereas Anchisauripus has intermediate values.

Analysis of the variation in AT with size throughout the sample (Fig. 6) shows that there is no direct correlation between the two parameters. Although it is true that the smallest specimen (MUJA-4124, FL $=7.9 \mathrm{~cm}$ ) is one of the most mesaxonic (AT $=0.85$ ), most of the sample is small-sized, with footprint length values of about 14-20 $\mathrm{cm}$ and AT values that are quite variable, ranging from 0.72 (MUJA-0627) to 1.12 (MUJA-1113). Thus, although 
the sample can be divided on the basis of size, this does not show the decrease in mesaxony that one might expect to distinguish between Anchisauripus and Grallator so it is not possible to distinguish between the two groups. The great variation in AT in specimens of similar length suggests that this parameter should be used with caution in distinguishing between different ichnotaxa.
Recent work has provided new data regarding the Eubrontes-like and Grallator-like tracks in Asia. Lockley (2009) suggested that even though a variety of ichnotaxonomic names are used, most of the tracks cannot be distinguished from the specimens of Eubrontes, Grallator and Kayentapus (Fig. 5e) from North America. Lockley et al. (2013) undertook an intensive review of

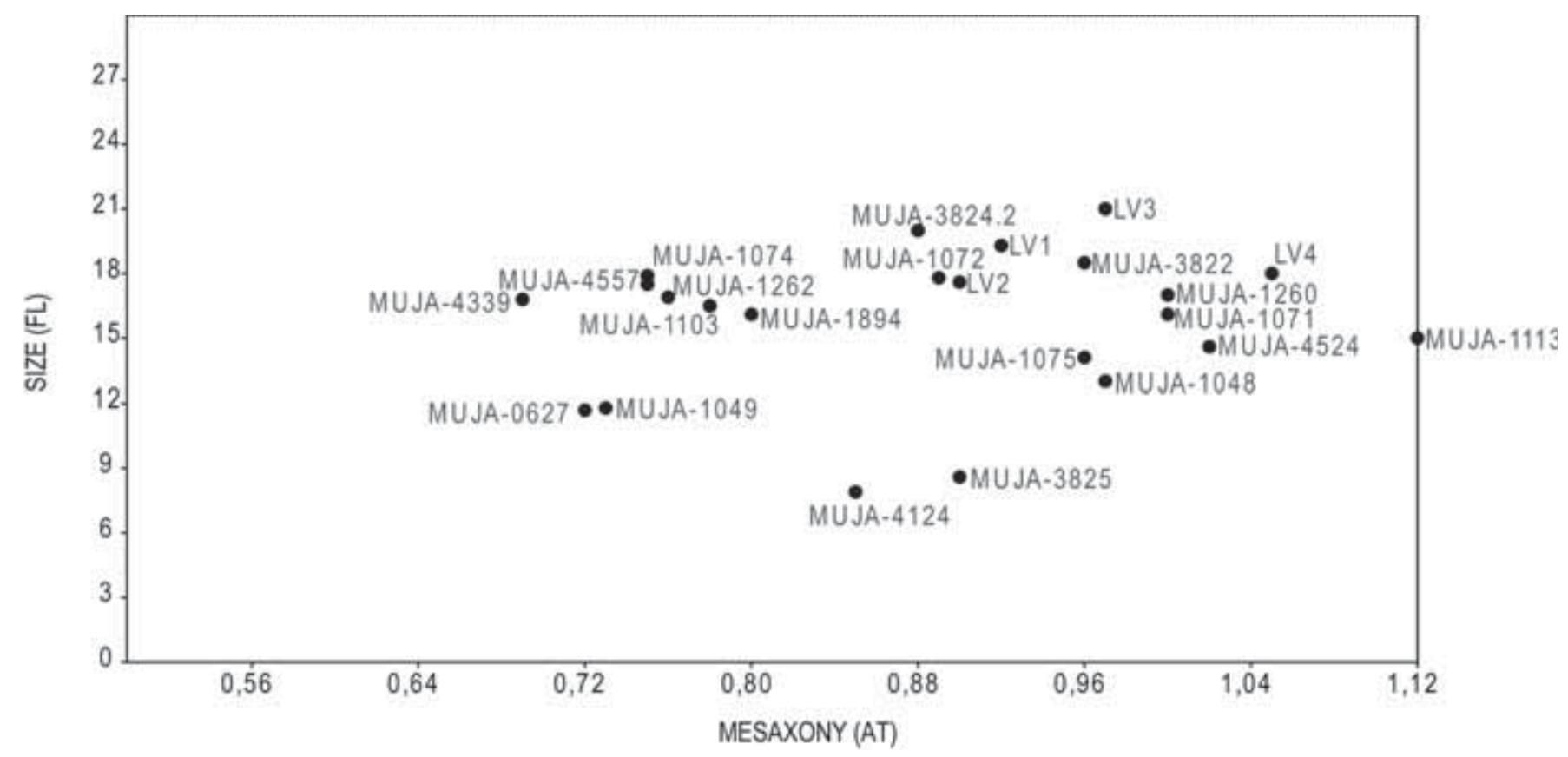

Figure 6. Bivariate graph plotting the footprint length vs AT (mesaxony) in the studied sample.

these tracks that reduced the number of theropod ichnotaxa, assigning some of the previous ichnospecies/ichnogenera to Grallator, Eubrontes and Kayentapus, especially for the Early and Middle Jurassic ichnotaxa. A bivariate analysis (Fig. 7a) of the AT and the footprint length/width ratio that includes the Asturian sample, the type material of Grallator-Anchisauripus and Eubrontes (Olsen et al., 1998) and other typical theropod ichnotaxa (especially several Asian ichnotaxa) (Lockley, 2009; Lockley et al., 2013) suggests that the majority of the specimens fall within the Grallator morphospace.

Among other Asian ichnotaxa, it is worth mentioning the ichnogenus Jialingpus (Fig. 5f) reported from the Late Jurassic and Early Cretaceous of China (Xing et al., 2014). Although Lockley et al. (2013) suggested that Jialingpus is Grallator-like and that "Grallator cannot be ruled out as the appropriate ichnotaxon for these specimens solely based on their Late Jurassic age", Xing et al. (2014) considered Jialingpus to be a valid ichnotaxon on the basis of the distinctively well-preserved pad, hallux and metatarsal traces. In fact, Jialingpus has been reported in other areas outside Asia, such as the Middle Jurassic of
Morocco (Gierliński et al., 2009a) and the Late Jurassic/ Early Cretaceous of Europe, as well as an Asturian tracksite in the sea cliff of Tereñes (not included in the studied sample) (Gierliński et al., 2009b). Jialingpus is characterized by 1) a large metatarsophalangeal area positioned in line with the axis of digit III, 2) the subdivision of this part into a small pad behind digit II, which in some specimens is close to the general position of the hallux (digit I), and a large metatarsophalangeal pad behind digit IV, and 3) a distinct inter-pad space between metatarsophalangeal pads and proximal phalangeal pads of digits II and III (Xing et al., 2014). The authors suggest that the main differences between Jialingpus and Grallator are the presence in the former of the hallux impression, the large metatarsophalangeal area and the widely divaricated digits. The authors also suggest that all Jialingpus specimens display a middle digit III that is strongly projecting. In contrast to tracks belonging to the Eubrontes-Anchisauripus-Grallator plexus, the metatarsophalangeal area is large, complex, elongated and located more centrally, behind digit III. This distinctive metatarsophalangeal area is regarded as a diagnostic 
feature of Jialingpus. The authors describe this area as a large pad behind digit IV and a smaller pad behind digit II and state that along with the hallux impression, these features are not seen in Grallator.

Gierliński et al. (2009b) compared specimens of similar size of Jialingpus and Grallator, noting that in the former the "heel" area represents $40 \%$ of the footprint length while in Grallator it only represents about $28 \%$. In the case of the studied sample, the "heel" area is small compared with the footprint length and it varies from $21-31 \%$ in the best-preserved specimens, so it would be more similar to Grallator than to Jialingpus. Further, a comparison of the values of the AT and FL/FW ratio that includes Jialingpus in the graphs shows that there is a small overlap with the Asturian sample but that the values in both parameters are generally lower in Jialingpus (Fig. 7b).

Among the other grallatorid-like ichnotaxa, mention should be made of Kalohipus bretunensis Fuentes Vidarte
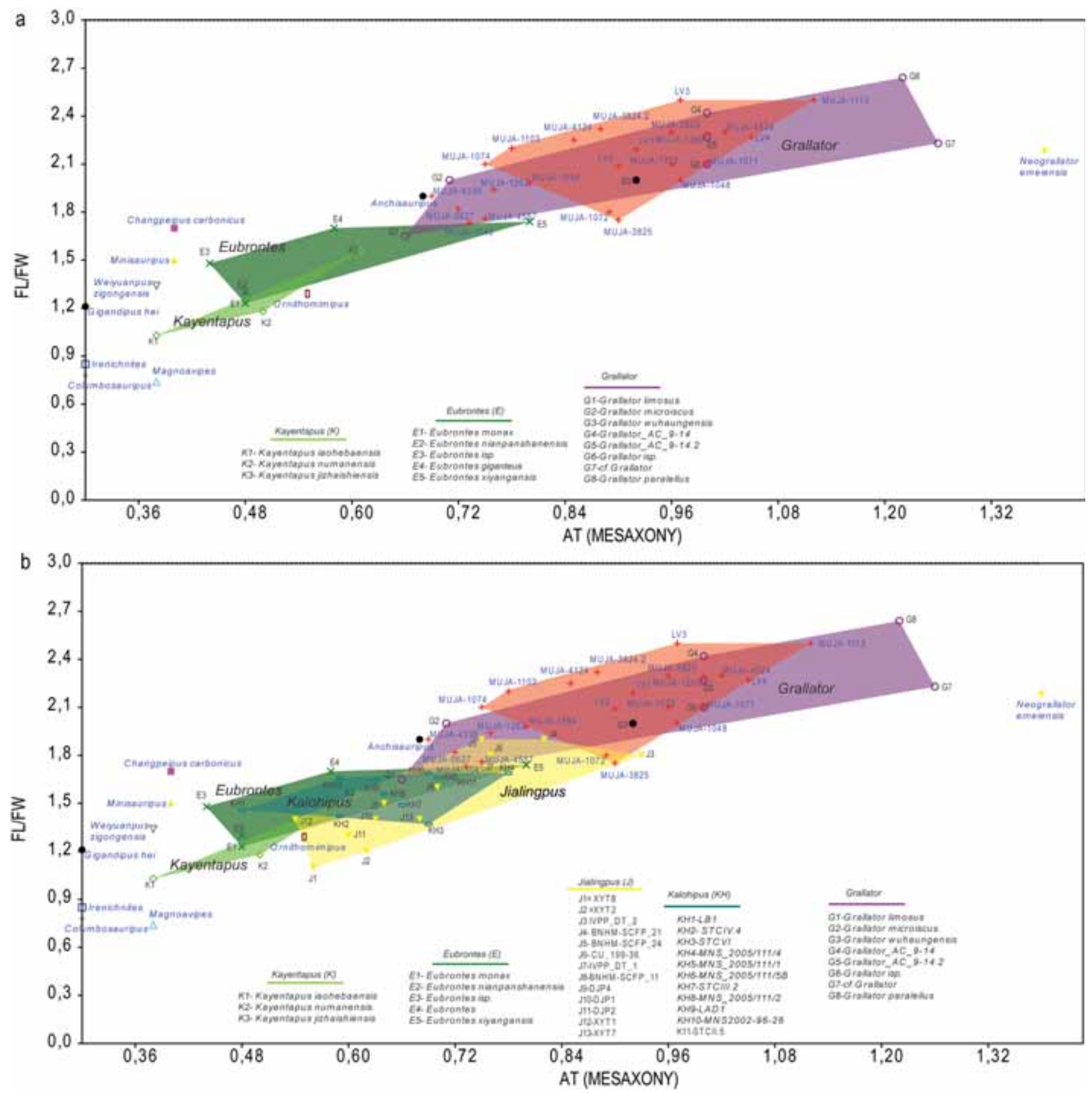

Figure 7. Bivariate graph plotting the footprint length/footprint width ratio vs AT of the main grallatorid-like ichnotaxa and some of the other theropod ichnotaxa. 
\& Meijide Calvo, 1998 (Fig. 5g). Comparison of the values of the AT and FL/FW ratio shows that there is also a small overlap with the Asturian sample but that the main values are lower in Kalohipus. Besides, recent landmark analysis has shown that this ichnotaxon is different from the type material of Grallator (Castanera et al., 2015). Comparison of the Asturian sample with the data reported by Castanera et al. (2015) brings certain differences to light. The PCA graph (Fig. 8) represents an analysis of the 25 specimens of grallatorid tracks from Asturias compared with the Kalohipus bretunensis tracks from the Huérteles Formation (Castanera et al., 2015) and the type material of GrallatorAnchisauripus and Eubrontes described by Olsen et al. (1998). The graph presents the scores of each individual track analysed. Three convex hulls can be clearly identified, one of them in the right area of the graph and the other two in the left area. The first convex hull represents the tracks belonging to Kalohipus bretunensis (right part of the graph). The second represents the analysed tracks from Asturias (large convex hull in the left part of the graph), and the third represents the data from the type material of Grallator parallelus (small convex hull in the left part of the graph). It is noteworthy that the morphospace of the latter is almost included within that of the sample of MUJA tracks. Furthermore, one of the tracks described by Olsen et al. (1998), AC9-14 (Anchisauripus), also fall within this morphospace while tracks AC4-6 (Anchisauripus), AC15-3 and AC45-1 (Eubrontes) do not.

The first four components (PC1 to PC4) represent a high percentage $(77 \%)$ of the morphological variation, PC1 containing almost $38 \%$ of the total shape variation (Table 3). The variables with the greatest weight in this PC are those related to landmarks 4 and 8 (most distal positions of digits IV and II, respectively), mainly

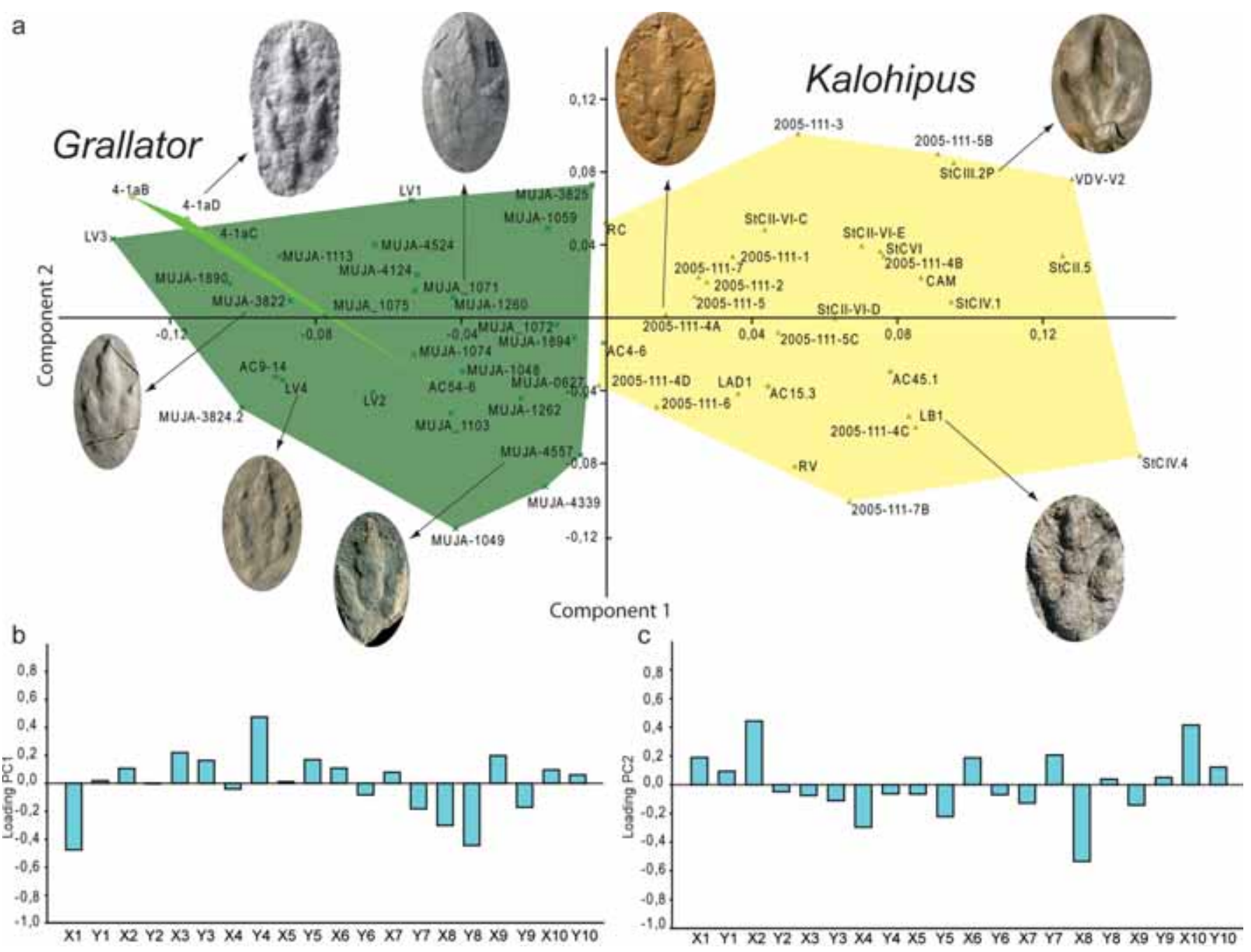

Figure 8. Results of the principal component analysis. a) Bivariate plot of the first two principal components (PC) in a sample including Kalohipus bretunensis, the Asturian sample and the type material of Grallator-Anchisauripus-Eubrontes. b) Relationship of each variable to the first PC shown by the eigenweight (loadings). c) Relationship of each variable to the second PC shown by the eigenweight (loadings). Picture of specimen 4-1aD, modified from Olsen et al. (1998). 
with respect to the $\mathrm{y}$-coordinate. Another variable with significant weight in this $\mathrm{PC}$ is related to landmark 1 (most distal position of digit III, mainly with respect to the $\mathrm{x}$-coordinate). The negative side of PC1 (scores < 0 ) represents tracks that have the lowest divergence of landmarks 4 and 8, and more projection of landmark 1. This means that tracks assigned to Grallator and the tracks from the Asturian sample have a lower divarication angle and a slightly longer digit III. In contrast, the positive side of PC1 (scores > 0) is the opposite, so tracks assigned to Kalohipus bretunensis and the tracks from the Asturian sample have a greater divarication angle and shorter digit III. This greater divarication as well as the variation in the position of landmark 1 suggests that there should be differences in mesaxony between Kalohipus bretunensis and the Asturian sample, as is shown in Figure 7. The second component (PC2) does not allow us to distinguish between the groups.

As it has been shown, digit divarication is indeed one of the differences between Grallator and other ichnotaxa

Table 3. Eigenvalues and percentage of variance obtained for the first ten principal components (PC) in the analysis.

\begin{tabular}{|c|c|c|}
\hline PC & Eigenvalue & $\%$ variance \\
\hline 1 & 0,005 & 37,947 \\
\hline 2 & 0,003 & 19,313 \\
\hline 3 & 0,001 & 10,994 \\
\hline 4 & 0,001 & 8,817 \\
\hline 5 & 0,001 & 4,943 \\
\hline 6 & 0,001 & 4,344 \\
\hline 7 & 0,000 & 3,570 \\
\hline 8 & 0,000 & 2,980 \\
\hline 9 & 0,000 & 2,025 \\
\hline 10 & 0,000 & 1,566 \\
\hline 11 & 0,000 & 1,130 \\
\hline 12 & $9,80 \mathrm{E}-5$ & 0,735 \\
\hline 13 & $7,51 \mathrm{E}-5$ & 0,564 \\
\hline 14 & $6,26 \mathrm{E}-5$ & 0,470 \\
\hline 15 & $3,94 \mathrm{E}-5$ & 0,295 \\
\hline 16 & $3,17 \mathrm{E}-5$ & 0,238 \\
\hline 17 & $9,14 \mathrm{E}-6$ & 0,069 \\
\hline 18 & $4,55 \mathrm{E}-16$ & $3,41 \mathrm{E}-12$ \\
\hline 19 & $2,65 \mathrm{E}-16$ & $1,99 \mathrm{E}-12$ \\
\hline 20 & $2,08 \mathrm{E}-16$ & $1,56 \mathrm{E}-12$ \\
\hline
\end{tabular}

such as Jialingpus. The variations in mesaxony are directly related to possible variations in digit divarication (Lockley, 2009). This author undertook an exhaustive discussion of possible variations in mesaxony as a consequence of extramorphological or preservational influences, depending on the substrate conditions. Trying to measure such influences, Lockley (2009) modeled two footprints with differences in digit lengths, concluding "digit divarication is of secondary importance in defining track morphology, including mesaxony, whereas relative digit length is of primary importance".

Taking into account that all the grallatorid-like ichnotaxa are characterised by the subequal length of digits II and IV and a longer digit III, and considering the great variation in AT in the Asturian sample, it is important to note that some of the differences in mesaxony seen among the ichnotaxa might represent the variation among individuals or preservational variations.

Finally, mention should be made of Lull's work in noting the difficulties of assigning the Asturian sample not just to Grallator or Anchisauripus but to ichnospecies of either ichnotaxa. Lull (1904) distinguished seven ichnospecies of Anchisauripus (dananus, hitchcocki, tuberosus, exsertus, minusculus, parallelus, tuberatus) and five of Grallator (cursorius, tenuis, cuneatus, formosus, gracilis). Some of the differences established by Lull (1904) among the Grallator-Anchisauripus ichnospecies relate to : 1) the divarication angle or differences in stride length (e.g. G. tenuis and G. cursorius), 2) the projection of digit III or the cuneiform shape of the foot (e.g. G. cuneatus vs Anchisauripus dananus), and 3) the size (e.g. G. formosus vs G. cuneatus). In fact, Lull suggested that Anchisauripus dananus "may prove to be identical at any rate with some of the specimens referred to" $G$. formosus. This implies that the differences between the ichnospecies are very subtle. Moreover, several of the Asian ichnospecies have been reassigned to Grallator and even now the differences with respect to other Grallator ichnospecies remain unclear (Lockley et al., 2013). In the light of the whole discussion of the morphological differences between ichnotaxa, the variations in ratios and the possible variations related to preservational factors, we have finally decided to assign the Asturian sample to Grallator isp.

\section{CONCLUSIONS}

The description of 25 specimens recovered from different localities on "The Dinosaur Coast" of Asturias (Kimmeridgian) suggests another evidence of grallatorid tracks in deposits younger than the Late Triassic-Early Jurassic interval. Comparison with tracks from the Eubrontes-Grallator plexus and other Grallator-like ichnotaxa prompts us to assign the tracks to Grallator isp. on the basis of the general morphology, the length/ width ratio, the mesaxony (which is high, although quite variable in the sample), the low divarication and the 
absence of hallux or metatarsophalangeal impressions. The PCA analysis based on 10 selected landmarks allows us to distinguish the Asturian sample from Kalohipus bretunensis, a grallatorid-like ichnotaxon described in the Cretaceous of the Cameros Basin (Soria). The Asturian sample provides new information on the persistence of Grallator in Late Jurassic deposits. The bivariate analysis of the length/width ratios and mesaxony and the PCA analysis open a new window onto the differentiation among some "grallatorid" ichnotaxa. Further work is needed in order to differentiate between the different ichnospecies/ ichnogenera responsible for the Grallator (sensu lato) tracks, especially those of the Late Jurassic and Early Cretaceous (cf. Lockley et al., 2015). Furthermore, taking into account the degree of overlap revealed by this analysis of the FL/FW ratio and the mesaxony among the Grallatorlike ichnotaxa, this work has opened up a new avenue for exploring how the digit lengths vary among the ichnotaxa (cf. Lockley, 2009) and whether they can be distinguished on the basis of this parameter.

\section{ACKNOWLEDGEMENTS}

This work was undertaken thanks to the help of a subsidy granted by the Sociedad Española de Paleontología within the framework of their Assistance for Research in the year 2015. DC is supported by the Alexander von Humboldt Foundation (Humboldt Research Fellowship for Postdoctoral Researchers) Research by LP was funded by the Project CGL2015-66835-P (Ministerio de Economía y Competitividad). The authors also thank Jorge Colmenar and Victor Sauque for their help with the statistical analysis. Rupert Glasgow revised the English grammar. The comments of Hendrik Klein and Spencer G. Lucas have helped to improve the manuscript and are greatly appreciated.

\section{REFERENCES}

Avanzini, M., Piñuela, L. \& García-Ramos, J.C. 2012. Late Jurassic footprints reveal walking kinematics of theropod dinosaurs. Lethaia, 45, 238-252; doi: 10.1111/j.15023931.2011.00276.x.

Castanera, D., Colmenar, J., Sauqué, V. \& Canudo, J.I. 2015. Geometric morphometric analysis applied to theropod tracks from the Lower Cretaceous (Berriasian) of Spain. Palaeontology, 58, 183-200; doi: 10.1111/pala.12132.

Clark, N.D.L. \& Brett-Surman, M.K. 2008. A comparison between dinosaur footprints from the Middle Jurassic of the Isle of Skye, Scotland, UK, and Shell, Wyoming, USA. Scottish Journal of Geology, 44, 139-150.
Clark, N.D.L., Ross, D.A. \& Booth, P. 2005. Dinosaur tracks from the Kilmaluag Formation (Bathonian, Middle Jurassic) of Score Bay, Isle of Skye, Scotland, UK. Ichnos, 12, 93-104; doi: 10.1080/10420940590914516.

Colmenar, J., Harper, D.A. \& Villas, E. 2014. Morphofunctional analysis of Svobodaina species (Brachiopoda, Heterorthidae) from south-western Europe. Palaeontology, 57, 193-214; doi: 10.1111/pala.12061.

De Valais, S. 2011. Revision of dinosaur ichnotaxa from the La Matilde Formation (Middle Jurassic), Santa Cruz Province, Argentina. Ameghiniana, 48, 28-42; doi: 10.5710/AMGH.v48i1(244).

Diedrich, C. 2011. Upper Jurassic tidal flat megatracksites of Germany - Coastal dinosaur migration highways between European islands, and a review of the dinosaur footprints. Palaeobiodiversity and Palaeoenvironments, 91, 129-155; doi: 10.1007/s12549-010-0044-y.

Fuentes Vidarte, C. \& Meijide Calvo, M. 1998. Icnitas de dinosaurios terópodos en el Weald de Soria (España). Nuevo icnogénero Kalohipus. Estudios Geológicos, 54, $147-152$.

García-Ramos, J.C. \& Gutiérrez Claverol, M. 1995. La Cobertera Meso-Terciaria. In: Geología de Asturias (eds Aramburu, C. \& Bastida, F.) Ediciones Trea, Gijón. 81-94.

García-Ramos, J.C., Lires, J. \& Piñuela, L. 2002. Dinosaurios: Rutas por el Jurásico de Asturias. La Voz de Asturias, Lugones, Asturias, Spain.

García-Ramos, J.C., Piñuela, L. \& Lires, J. 2004. Guía del Jurásico de Asturias. Rutas por los Yacimientos de Huellas de Dinosaurios. Zinco Comunicación, Gijón.

García-Ramos, J.C., Piñuela, L. \& Lires, J. 2006. Atlas del Jurásico de Asturias. Ediciones Nobel, Oviedo.

Gaston, R., Lockley, M., Lucas, S. \& Hunt, A. 2003. Grallator-dominated fossil footprint assemblages and associated enigmatic footprints from the Chinle Group (Upper Triassic), Gateway area, Colorado. Ichnos, 10, 153-163; doi: 10.1080/10420940390256258.

Gatesy, S.M., Middleton, K.M., Jenkins Jr, F.A. \& Shubin, N.H. 1999. Three-dimensional preservation of foot movements in Triassic theropod dinosaurs. Nature, 399, 141-144; doi: 10.1038/20167.

Getty, P.R., Hardy, L. \& Bush, A. M. 2015. Was the Eubrontes track maker gregarious? Testing the herding hypothesis at Powder Hill Dinosaur Park, Middlefield, Connecticut. Bulletin of the Peabody Museum of Natural History, 56, 95-106; doi: 10.3374/014.056.0109.

Gierliński, G.D. 1991. New dinosaur ichnotaxa from the Early Jurassic of the Holy Cross Mountains, Poland. Palaeogeography, Palaeoclimatology, Palaeoecology, 85, 137-148; doi: 10.1016/0031-0182(91)90030-U.

Gierliński, G.D. \& Ahlberg, A. 1994. Late Triassic and Early Jurassic dinosaur footprints in the Höganäs Formation of southern Sweden. Ichnos, 3, 99-105; doi: 10.1080/10420949409386377.

Gierliński, G.D., Menducki, P., Janiszewska, K., Wicik, I. \& Boczarowski, A. 2009a. A preliminary report on dinosaur track assemblages from the Middle Jurassic of the Imilchil area, Morocco. Geological Quarterly, 53, 477-482. 
Gierliński, G.D., Niedźwiedzki, G. \& Nowacki, P. 2009 b. Small theropod and ornithopod footprints in the Late Jurassic of Poland. Acta Geologica Polonica, 59, 221-234.

Hammer, Ø., Harper, D.A.T. \& Ryan, P.D. 2001. PAST: paleontological statistics software package for education and data analysis. Palaeontologia Electronica, 4, 1-9.

Hitchcock, E. 1858. Ichnology of New England. A Report on the Sandstone of the Connecticut Valley, Especially its Fossil Footmarks. William White, Boston.

Klein, H. \& Haubold, H. 2007. Archosaur footprintspotential for biochronology of Triassic continental sequences. In: The Global Triassic (eds Lucas, S.G. \& Spielmann, J.A.) New Mexico Museum Natural History Science Bulletin, 41, 120-130.

Lockley, M.G. 2009. New perspectives on morphological variation in tridactyl footprints: clues to widespread convergence in developmental dynamics. Geological Quarterly, 53, 415-432.

Lockley, M.G. \& Gierliński, G.D. 2014. Jurassic tetrapod footprint ichnofaunas and ichnofacies of the Western Interior, USA. Volumina Jurassica, 12, 133-150; doi: 10.5604/17313708.1130134.

Lockley, M.G., García-Ramos, J.C., Piñuela, L. \& Avanzini, M. 2008. A review of vertebrate track assemblages from the Late Jurassic of Asturias, Spain with comparative notes on coeval ichnofaunas from the western USA: implications for faunal diversity in siliciclastic facies assemblages. Oryctos, 8, 53-70.

Lockley, M.G., Gierliński, G.D. \& Lucas, S.G. 2011. Kayentapus revisited: notes on the type material and the importance of this theropod footprint ichnogenus. Fossil Record 3: New Mexico Museum of Natural History and Science, Bulletin, 53, 330-336.

Lockley, M.G., Li. J.I., Li, R.H., Matsukawa, M., Harris, J.D. \& Xing, L. D. 2013. A review of the tetrapod track record in China, with special reference to type ichnospecies: implications for ichnotaxonomy and paleobiology. Acta Geologica Sinica (English Edition), 87, 1-20; doi: 10.1111/1755-6724.12026.

Lockley, M.G., Xing, L.D., Kim, J.Y. \& Matsukawa, M. 2014. Tracking Lower Cretaceous dinosaurs in China: a new database for comparison with ichnofaunal data from Korea, the Americas, Europe, Africa and Australia. Biological Journal of the Linnean Society, 113, 770-789; doi: 10.1111/bij.12308.

Lockley, M.G., Li, R.H., Matsukawa, M., Xing, L.D., Li, J.J., Liu, M.W. \& Xu, X. 2015. Tracking the yellow dragons: Implications of China's largest dinosaur tracksite (Cretaceous of the Zhucheng area, Shandong Province, China). Palaeogeography, Palaeoclimatology, Palaeoecology, 423, 62-79; doi: 10.1016/j. palaeo.2015.01.028.

Lucas, S.G., Hunt, A.P. \& Lockley, M.G. 2001. Tetrapod footprint ichnofauna of the Upper Triassic Redonda Formation, Chinle Group, Quay County, New Mexico. New Mexico Geological Society Guidebook, 52, 177-180.

Lucas, S.G., Klein, H., Lockley, M.G., Spielmann, J.A., Gierlinski, G.D., Hunt, A.P. \& Tanner, L.H. 2006.
Triassic-Jurassic stratigraphic distribution of the theropod footprint ichnogenus Eubrontes. In: The Triassic-Jurassic Terrestrial Transition (eds Harris, J.D., Lucas, S.G., Spielmann, J.A., Lockley, M.G., Milner, A.R.C. \& Kirkland, J.I.). New Mexico Museum of Natural History and Science Bulletin, 37, 86-93.

Lucas, S.G., Spielman, J.A., Klein, H. \& Lerner, A.J. (eds). 2010. Ichnology of the Upper Triassic (Apachean) Redonda Formation, East-Central New Mexico. New Mexico Museum of Natural History and Science, Bulletin 47, p. 75.

Lull, R.S. 1904. Fossil Footprints of the Jura-Trias of North America. Memoirs of Boston Society Natural History, 5, 461-557.

Marty, D. 2008. Sedimentology, taphonomy, and ichnology of Late Jurassic dinosaur tracks from the Jura carbonate platform (Chevenez-Combe Ronde tracksite, NW Switzerland): insights into the tidal-flat palaeoenvironment and dinosaur diversity, locomotion, and palaeoecology. Geofocus, 21, 278 p.

Milàn, J., Clemmensen, L. \& Bonde, N. 2004. Vertical sections through dinosaur tracks (Late Triassic lake deposits, East Greenland)-undertracks and other subsurface deformation structures revealed. Lethaia, 37, 285-296; doi: 10.1080/00241160410002036.

Olsen, P.E. 1980. Fossil Great Lakes of the Newark Supergroup in New Jersey. In: Field Studies of New Jersey Geology and Guide to Field Trips (ed. Manspeizer, W.). 52nd Annual Meeting New York State Geology Association, Newark College of Arts and Sciences, Newark, Rutgers University, 352-398.

Olsen, P.E., Smith, J.B. \& McDonald, N.G. 1998. Type material of the type species of the classic theropod footprint genera Eubrontes, Anchisauripus, and Grallator (Early Jurassic, Hartford and Deerfield basins, Connecticut and Massachusetts, USA). Journal of Vertebrate Paleontology, 18, 586-601.

Pascual-Arribas, C. \& Hernández-Medrano, N. 2012. Posibles huellas de crías de terópodo en el yacimiento de Valdehijuelos (Soria, España). Studia Geologica Salmanticensia, 47, 77-110.

Petti, F.M., Bernardi, M., Ferretti, P., Tomasoni, R. \& Avanzini, M. 2011. Dinosaur tracks in a marginal marine environment: the Coste dell'Anglone ichnosite (Early Jurassic, Trento Platform, NE Italy). Italian Journal of Geoescience, 130, 27-41; doi: 10.3301/IJG.2010.19.

Piñuela, L. 2000. Icnitas de dinosaurios bípedos del Jurásico de Asturias. Morfometría, morfología e interpretación. Trabajo de Investigación, Universidad de Oviedo, 63 p (unpublished).

Piñuela, L. 2015. Huellas de dinosaurios y de otros reptiles del Jurásico Superior de Asturias. Ph.D. Thesis, University of Oviedo, 326 p (unpublished).

Rainforth, E.C. 2005. Ichnotaxonomy of the fossil footprints of the Connecticut Valley (Early Jurassic, Newark Supergroup, Connecticut and Massachusetts). Ph.D. Thesis, Columbia University, 1301 p.

Rasskin-Gutman, D., Hunt, G., Chapman, R.E., Sanz, J.L. \& Moratalla, J.J. 1997. The shapes of tridactyl dinosaur 
footprints: procedures, problems and potentials. In: Dinofest International Symposium (eds Wolberg, D.L., Stump, E. \& Rosenberg, G.D.). Academy of Natural Sciences, Philadelphia, 377-383.

Rodrigues, L.A. \& Santos, V.F. 2004. Sauropod Tracks - a geometric morphometric study. In: Morphometrics. Applications in Biology and Paleontology. (ed. Elewa, A.M.T.). Springer-Verlag, New York, 129-142.

Smith, J.B. \& Farlow, J.O. 2003. Osteometric Approaches to Trackmaker Assignment for the Neward Supergroup Ichogenera Grallator, Anchisauripus, and Eubrontes. In: The Great Rift Valleys of Pangea in Eastern North America, Volume 2: Sedimentology, Stratigraphy and Paleontology (eds Letourneau, P.M. \& Olsen, P.E.). Columbia University Press, New York, 273-292.

Thulborn, R.A. 1990. Dinosaur tracks. Chapman and Hall, London.

Thulborn, T. 2000. Australia's earliest theropods: footprint evidence in the Ipswich Coal Measures (Upper Triassic) of Queensland. In: Aspects of Theropod Paleobiology (eds Pérez-Moreno, B.P., Holtz, T., Sanz, J.L. \& Moratalla, J.J.). Gaia, 15, 301-311.

Weems, R.E. 1992. A re-evaluation of the taxonomy of Newark Supergroup saurischian dinosaur tracks, using extensive statistical data from a recently exposed tracksite near Culpeper, Virginia. In: Proceedings of the 26th Forum on the Geology of Industrial Minerals (ed. Sweet, P.C.). Charlottesville, VA, Virginia Division of Mineral Resources, 119, 113-128.

Xing, L.D., Lockley, M.G., Klein, H., Gierliński, G.D., Divay, J.D., Hu, S.M., Zhang, J.P., Ye, Y. \& He, Y.P. 2014. The non-avian theropod track Jialingpus from the Cretaceous of the Ordos Basin, China, with a revision of the type material: implications for ichnotaxonomy and trackmaker morphology. Palaeoworld, 23, 187-199; doi: 10.1016/j. palwor.2013.12.001. 